\title{
Unlocking the Challenging Pathways of Youth Participation in Ghana's Youth Employment and Entrepreneurial Development Agency
}

\author{
Edward Brenya, Dominic Degraft Arthur, Janet Nyarko \\ History and Political Studies, Kwame Nkrumah University of Science and Technology, Ghana \\ ebrenya@gmail.com
}

\begin{abstract}
Youth participation in public policies such as the employment policy process has gained prominence in academic and policy literature. Despite this, research on youth participation in the employment policy process has received little attention in Ghana. This paper draws on documentary analysis to unlock the challenging pathways of youth participation in Ghana's youth employment and entrepreneurial development agency. The paper finds that a web of challenges such as insufficient access to information, overpoliticization of GYEEDA, poor level of coordination of stakeholders, and prevalence of diversity and social exclusion are embedded in obstructing the youth participation in GYEEDA. The study recommends that policymakers such as the government and other stakeholders should provide adequate measures to ensure that beneficiaries such as the youths are engaged in the design, formulation, and execution of the youth employment policy process in Ghana.
\end{abstract}

Keywords: Youth, participation, employment, policy formulation, and policy implementation.

\section{Introduction}

Generally, an interest in youth participation in public policy-making processes, as a field of study and a policy instrument has increased in the contemporary period (Bessant, 2018; Dalton, 2017). Existing literature defines youth participation as a change process and proactive learning by doing exercise, with youths at the center of the development programs and processes. Arguably, youth participation in the public policy process is conceived as the strongest predictor that aids in strengthening the existing capacities of the youth, and the formation of social networks in the society (Sloam, 2016; Tsekoura, 2016). Typically, scholarly literature on youth participation in the public policy process is replete with competing perspectives. Each of these strands repeatedly sheds light on the question of youth participation in the public policy process (Hart \& Henn, 2017; Chamisa \& Shava, 2016). For instance, according to the realists, young people in the contemporary era are determined and overly ambitious to participate in the public policy process so that they can discharge their civic duties and obligations toward society (0’Toole, 2015; Sloam, 2016). Along these lines, Côté (2014) also posited that youth participation in public policies and initiatives is crucial because youth are energetic, exhibit more curiosity, creativity, concern, and enthusiasm, thus, involving young people in the public policy process upholds their rights as citizens. These observations are aptly supported by Busse, Hashem-Wangler, \& Tholen, (2015) study which argued that youth participation in public policy processes such as employment policy has an intrinsic normative value.

Which therefore prepares and engages them to renew their civic responsibilities in the society? This shift has been particularly noticeable among many countries in Africa, where collective action via youth involvement in policymaking processes such as employment policy has become common practice (Busse, HashemWangler, \& Tholen, 2015). Conversely, another stream of thought argues that youths are less potent than adults since they are in the process of becoming mature, consequently, they are regarded as citizens under training, thus, they are likely to exhibit some forms of immaturity leading to biases and heuristics in their decision making, when given a platform to participate in the public policy process (Mycock \& Tonge, 2012). Also, it is claimed that the engagement of citizens or groups (such as youths) in every public policy process and its execution ordinarily delay the quick decision-making process on policies, because they do not have the required experience and knowledge on the subject matter of the policy process (Mycock \& Tonge, 2012). Despite these caveats, scholarly explanation contends that the drive for youth participation in the public policy process is in accordance with the advocacy of international organizations (Checkoway, 1998). First, Article 12 of the United Nations Convention on the Rights of Children advocates for youth to participate in policies and programs that unswervingly affect their lives (United Nations, 2003). Second, priority 10 of the World Programme of Action for Youth from the Year 2000 and beyond argues that 'greater engagement of 
youth in public policy process facilitate in building their capacity to promote the socio-economic development of their society (United Nations , 2007).

As consequence, across the African continent, numerous steps have also been taken to hasten youth engagements in the public policy process. For example, in 2006, the African Youth Charter was officially approved in Banjul, the Gambia by Heads of States to resolve concerns related to youth policies (Economic Commission for Africa, 2011). Besides, the Assembly of the African Union conference held in February 2009 in Addis Ababa declared the period of 2009-2018 as Decade of Youth Development in Africa. Similarly, in 2010, African Ministers responsible for youth policies officially approved the projected proposal of action for the Decade (2009-2018) for Youth Development. This declaration markedly supports the African Union's demand for member states to sanction the execution of the African Youth Charter. Nonetheless, some governments in African countries failed to fully implement national youth policies (African Union, 2011). In response to the preceding paradoxes, during the 17th Ordinary Summit held from 23rd June to 1st July 2011 in Malabo, Equatorial Guinea, African governments were required to hasten the execution of the Youth Decade Plan of Action (2009-2018) and the African Youth Charter. Again, African governments were further tasked to assiduously resolve youth unemployment in line with the Ouagadougou 2004 Plan of Action on Employment and Poverty Alleviation. Furthermore, during the 8th Session of the African Union Labour and Social Affairs Commission in 2011, African ministers promised to help reduced youth unemployment by $2 \%$ per annum through the development, financing, and execution of Youth Employment Action Plans (African Union , 2011).

In the context of Ghana, the implementation of the African Youth Charter in 2010 documented that every young person in the country has the right to be involved in all domains of society (Article 11). Typically, the Charter (Article 12) concluded that consultations and active participation of the youth should be made during decision-making on issues concerning the youth in the state. In the search for support from the youth, most manifestos of political parties premised around the engagement of the youth which forms the majority of the population (Gyampo \& Debrah, 2012). Linked with the preceding provisions, in the year 2012, Ghana witnessed a rise in the participation of youth (within the ages of 21 and 40 years) in both public and political offices. For example, the fifth parliament of the Fourth Republic recorded forty-four (44) youths elected as parliamentary members (Gyampo, 2015). Taken together, as Gyampo (2015) bemoans, while there were a sizable number of youths as members of parliaments represented in national decision making at Ghana's fifth parliament, they scarcely articulate their views to promote accountable and responsible government in that regime. This observation aptly resonates in Grauenkaer \& Tufte (2018) seminal study that, even though in most of the Africa countries, many youths have the opportunity to represent their constituents in national policymaking processes, their level of influence is very unreliable because they are more responsive to their interests and the interest of wealthier individuals who supported them to secure the position than to average citizens (Gyampo \& Obeng-Odoom, 2013). Also, issues concerning youths are deliberated and executed by policymakers who do not have sufficient and technical knowledge of youth activities. Therefore, adults are better positioned to participate in decision-making than youth.

Because they believe that youths are inexperienced to decide on policies for themselves (Gyampo \& ObengOdoom, 2013). Technically, although there is growing interest in youth participation in the public policy process in Ghana, there are few empirical studies that are conducted in this subject area, with scholars such as Gyampo (2015), Gyampo \& Obeng-Odoom (2013), Gyampo \& Debrah (2012), and Gutmann \& Thompson (2004) as seminal contributors. Thus, this current paper attempts to explore the challenging pathways of youth participation in Ghana's youth employment and entrepreneurial development agency. Ghana is an ideal arena to use as a case study because, she is among few countries in sub-Saharan Africa that implemented youth policy in the 1970s, and consequently, Ghana has numerous experiences and paradoxes on youth engagement in the public policies process. This paper makes a relevant contribution to the extant literature in public administration and political science. In terms of methodological contribution, this study combines data from national and district levels for analysis of youth participation in the public policy process. Thus, the findings are likely to help the government and policymakers to appreciate the web of economic and sociocultural conditions that impede youth participation in the public policy process so that they can design realistic and extensive policies to resolve them. This development will, therefore, facilitate maximizing the utility and harnessing productive assets of the youth to contribute towards state development. The rest of the 
paper is categorized as follows; this introduction is followed by an appraisal of Ghana's youth employment and entrepreneurial development agency (GYEEDA), conceptual and theoretical frameworks, methodological approach, followed by findings and discussion. The paper ends with a conclusion and implications for policy.

Ghana Youth Employment and Entrepreneurial Development Agency: The successive and current government's desire to resolve youth unemployment issues inclusively began in 1999 when the draft national youth policy was formulated by the Ministry of Youth and Sports in Ghana (NDPC , 2010). One such policy was the National Youth Employment Programme (NYEP) launched by the New Patriotic Party (NPP) to empower young people to contribute meaningfully to the socio-economic and sustainable development of the society (NDPC, 2010). The NYEP launched by the NPP government headed by John Agyekum Kuffour and implemented at the national, regional, and district levels was originally begun with nine modules. New modules were periodically created and added to the program (Ghana Statistical Service , 2014). The program aimed at creating half a million self-employment jobs, wage-earning jobs, and voluntary service activities in 3 years from 2006-2009 to help ameliorate the mass drift of the youth, especially basic and secondary school graduates as well as others who have lost interest in agriculture and rural life in general to urban centers in Ghana in search of jobs. Furthermore, the program was also focused on the provision of essential social services that promote good governance, access to good education, and health services to citizens in Ghana (Ghana Statistical Service , 2014). The program was funded by District Assembly Common Fund (DACF), Ghana Education Trust Fund (GET Fund), National Health Insurance Scheme (NHIS), Road Fund, Highly Indebted Poor Country (HIPC) and the Millennium Development Accounts (Republic of Ghana, 2006).

Also, further funding of five (5) million Euros was provided by DANIDA to support Phase One of the initiative aimed at supporting persons with disabilities (PWDs) in implementing the Aso-Kente factory in the Volta Region, and the chalk facility in the Greater Accra Region. An additional ten (10) million Euros was released by DANIDA under Phase Two to support other beneficiaries throughout the country (Ministry of Youth and Sports, 2013). Following the election in 2008, National Democratic Congress (NDC), which formed a new government, restructured the National Youth Employment Programme (NYEP) of the erstwhile government headed by John Agyekum Kuffour. In the first phase, the government decoupled the youth programs from the Ministry of Manpower Development and Employment and attached them to Sports, and consequently created a new Ministry of Youth and Sports. The second phase was the development of a new draft National Youth Policy to replace the previous youth policy. The new National Youth Policy was inaugurated on August 13, 2009, at Elmina in the Central Region. The National Youth Council (National Youth Authority [NYA]) was assigned the responsibility of implementing, monitoring, and evaluating Ghana Youth Employment and Entrepreneurial Development Agency (GYEEDA) of government headed by President John Mahama (Ghana Statistical Service , 2014). The youth policy stands out as key important public interventions targeting youth development in Ghana. Technically, in terms of employment, in 2006, there were 78,195 youths employed in the program nationwide. Similarly, in May 2007, there were 95,000 youths employed in the program. Also, there were 108,000 youths recruited, trained, and employed in February 2011 in the program (NDPC , 2010).

\section{Conceptual and Theoretical Frameworks}

Youth Participation in Employment Policy: The concept of youth is defined in diverse ways, but it is commonly conceptualized based on chronology, and life transitions. Chronologically, the concept of youth is conceived as people aged between 15 and 24 years. In terms of transitions in life, youth are mostly categorized between childhood and adulthood (Gough, Langevang, \& Owusu, 2013). Accordingly, the transitions approach to defining youth mostly focuses on the transitions to education, the world of work, and family formation. Nonetheless, these three standards could differ from one geographical region, country, or culture to the other due to quick socio-economic transformations caused by globalization, formal education, and migration (Langevang, 2008). According to the Africa Union, youth is defined as people aged between 15 to 34 years. This definition is espoused in this paper because it resonates with that of the National Youth Policy of Ghana (Ghana Statistical Service, 2012). In essence, the academic literature has made large strides towards the understanding of youth participation in the public policy process (Checkoway, 1998). One such influential study on this topic was conducted by (Gaiser, ve, \& Spannring, 2010). They argue that a country's level of development has a positive correlation with the active participation of youth in decision-making. At its core, Gaiser, ve, \& Spannring (2010) contend that, across the countries in Africa continent, most of the 
young people have less or no education and hence are not better equipped for job opportunities than adults. Akin to the preceding views, the analysis of the existing literature also highlights that in many Africa societies, cultural factors hinder most youth groups in society from participating in the public policy processes (Greetje, 2009).

For example, according to Greetje (2009), the influence of patriarchy is among the cultural philosophical factors that affect youth participation in the decision-making process. Patriarchy describes man as one that manages and leads decision-making in the family and society. Thus, this philosophy entrusts power and control of resources into the adults, making youth incapacitated in contributing to the policy-making process. In addition, Molloy, White, \& Hosfield (2002) in an analysis of youth participation in employment policy indicate the practice demonstrates that the rise of institutions, whether cultural or the outcome of a policy, from time to time involves some types of social organizations that have an enduring and somewhat deciding factor on the behavior of institutions today. As espoused by scholars, in the colonial era, institutions and the political system were built around men in most African countries. Men were invariably in charge of all key and important positions. At the initiation and implementation of a policy even at the central and local level, long-standing traditions favored men over every other group in society by making them the key decisionmakers in the society. These have consequently affected institutions today by giving men more opportunities over young people in the decision-making process. This assertion suggests that men in society are better experience and knowledgeable in appreciating issues that focusing on youth than the youth themselves in society (Molloy, White, \& Hosfield, 2002). Scholarly explanation further reveals that in many countries in Africa.

Youth are side-lined at the local and central level of the decision-making process (Malley, 2005) because they are largely considered second class citizen that cannot compete with the male adult who is regarded as the first-class citizen in society. Consequently, the second-class citizens serve as aids to the male adults and not necessarily to spearhead the decision-making process and implementation. This institutional arrangement creates an impetus for society to prejudice against youth participation in the public policy process. Building on preceding perspectives, influential literature also shows that poverty is one of the key determinants that impede youth participation in the policy-making process (Percy-Smith \& Thomas, 2009). At its core, the scholars underscored that many youths are out of jobs and therefore see themselves as not fit to be involved in the decision-making process. This is imperative because most community members have the impression that youth involvement in employment interventions and policies entails some costs in terms of their time, labor, and resources. As a consequence, some of them may fail to involve themselves in such employment interventions and policies especially when these activities require cash contributions. Congruently, Dowding (1996) also argues that youth engagement in the policy process is a key aspect of good governance, but in Africa, politics is made an integral part of the policy-making process since the policy is not made in a controlled environment with neutral policymakers. This phenomenon, therefore, creates an impetus for society to prejudice against youth participation in the public policy process.

The Theory of Social Interdependence: The theory of social interdependence which is associated with Deutsch (1962) is commonly used in political science and sociology discourse. The review of theory focuses on providing a foundation to help analyze the dynamics of youth participation in the Ghana Youth Employment and Entrepreneurial Development Agency. In their seminal study, Johnson \& Johnson (2010) argue that the social interdependence theory is premised on the basic idea that the structured goals which are pursued by individuals in a situation regulate how stakeholders co-operate and interact to achieve these goals. Furthermore, the writers bemoaned that the nature and type of interdependence determine the nature of the interaction among stakeholders. Embedded in this interaction are the prospects of promoting and facilitating goal attainment, or thwarting the attainment of the goals. As espoused by Johnson \& Johnson (2010), social interdependence can occur in positive or negative ways.

Also, in other instances, there may be no social interdependence (Johnson \& Johnson, 2010). Positive interdependence denotes the situation where each stakeholder in the policymaking process is dependent on the contributions of other stakeholders and that all members have a common goal attainable only by working together (Falls et al., 2014) which brings out the best in each member and enhances goal achievement at a superior level than as individuals (Tarricone \& Luca, 2010). Negative interdependence results in conflicting 
interactions such as stakeholders thwarting each other's determinations in realizing their goals, whilst no interdependence tends to result in the absence of interactions. Technically, several studies on social interdependence investigate the nuances of collaboration, where active cooperation is dependent on individual accountability, positive interdependence, and the procedures leading to the effectiveness of stakeholder activities in the policymaking process (Johnson \& Johnson, 2010). Inspired by the work of Johnson \& Johnson (2010), some scholars such as Tarricone \& Luca (2010) well admitted that there exists a strong connection.

Between teamwork and social interdependence because successful stakeholder interactions are largely contributed by various factors such as positive interdependence which bothers on team members relying on each other to succeed; one which bothers on face-to-face primitive interaction; teamwork skills that promote, communication, conflict management, and trust-building; as well as problem-solving and team decisionmaking for policy completion. In contrast, some scholars also echoed that other forces including emotional disturbances, social insensitivity, and ineffectual teamwork among stakeholders, interpersonal skills, and learning to trust each other in the team tend to reduce the level of interdependence among stakeholders to accomplish the goals of a policy, and thus could lead to failure of the policymaking process (Brown \& Paulus, 2002). The social interdependence theory was adopted to guide this study because the theory presents an impeccable opportunity to evaluate the success or failure of youth participation in the public policy process in a theoretically plausible way. According to the theory, the success of youth participation in the public policy process lies in the collaboration between stakeholders as a team in developing and implementing youth policies. Also, the theory contends that ineffectual teamwork among stakeholders can lead to their isolation from the groups, which can lead to vindictive relationships among the youth, leading to the ultimate failure of the policymaking process (Brown \& Paulus, 2002).

\section{Methodological Approach}

Study Design and Approach: The researchers adopted the desk review method by relying on current secondary literature on youth participation in the public policy process. Secondary data were sourced from the Kwame Nkrumah University of Technology Library and also journal articles from Google Scholar and Google. These key online databases were utilized because they are broad-based data that cut across various disciplines. Data was collected in two months, which began on $14^{\text {th }}$ April 2019 and completed on $15^{\text {th }}$ June 2019 based on the research questions outlined for the study. The literature search yielded about sixty -two (62) secondary documents. These documents were derived from three sources such as books, policy documents, and peer-review journal articles. These documents were analyzed to ensure that pertinent materials that focused on youth participation in public policy processes were only selected for critical review for the study.

Data Extraction and Analysis: The analysis of data for the study was fully manual. The analytical method was primarily thematic and coding was mainly inductive (Patton, 2002). For analytical triangulation, data extraction from qualitative studies was conducted by synthesizing similar themes that touched on youth participation in the public policy process. As part of the analysis, inconsistencies were reconciled by referring to the original text. The codes (themes) agreed upon by researchers' analysts were characterized into key themes and sub-themes for the analysis of the study.

\section{Results and Discussion}

This section presents the results and discussion of the study. Key findings that emerged from the analysis of data are described under the following themes: insufficient access to information, over-politicization of the policy process, level of coordination of stakeholders, and prevalence of diversity and social exclusion.

Insufficient Access to Information on GYEEDA: Data revealed that the youth did not have sufficient access to information to dialogue about the existence of GYEEDA, and the benefits they could gain from participation in such a policy. Data showed that youths' inability to access sufficient information on GYEEDA was mainly caused by the poor level of education on the GYEEDA by the policymakers and other stakeholders, poor access to the use of the internet to access the programs and activities of GYEEDA that were displayed on the 
Agency's website, and cost involved in accessing this information from the internet. Besides, the internet network system is very poor in many parts, especially the rural communities of the country, therefore, if programs and activities of GYEEDA were displayed on its website, there is a likelihood that, only a few youths, who are educated could access them, consequently, the educated elites are better positioned to access and subsequently participate in GYEEDA programs and activities. This finding is consistent with Gaiser, ve, \& Spannring (2010), conclusion that many of the young people in Africa countries have less or no education, as a result, they are not better equipped for job opportunities than adults, consequently, adults are better positioned to participate in employment process than the youth in the society.

Over-Politicisation of the Policy Process: Over-pollicisation of GYEEDA was also identified in the study. Data documented that as authorized by the National Youth Act 1974, a prerequisite for the engagement in the employment public policy process is that youth organizations have to register with the National Youth Authority. Data further documented that per the National Youth Act 1974, the youth authority is mandated to use the registration lists to invite youth groups for their engagement in the youth policies and activities. However, available evidence from the field showed that policymakers did not create favorable conditions to enable them to participate in the design of the GYEEDA program and activities by the National Youth Authority. For example, a report from the field revealed that throughout its life, GYEEDA was poorly managed by the dishonest policymakers and elites' in the then ruling National Democratic Party government to perpetuate their political patronage for the national elections in 2016. A report from the field established that Ministers of state openly come out on air to propagate the ruling government's agenda on GYEEDA. It was established from the study that national coordinators of GYEEDA used the scheme to reward the card-bearing members and sympathizers who canvassed for votes for the National Democratic Congress to win the 2008 national election to the neglect of the youth, who are the beneficiaries of the program. This finding confirms Dowding's (1996) conclusion that politics is an integral part of policy-making since the policy is not made in a controlled environment with neutral policymakers. This phenomenon, therefore, creates an impetus for society to prejudice against youth participation in the public policy process.

Level of Coordination of Stakeholders: Data further showed that there was a poor level of coordination of stakeholders of GYEEDA. For example, according to the data from the field, officials of GYEEDA did not coordinate with the youth who ought to be the primary stakeholders of the program. The policymaking process was dominated by members of the youth wing of the National Democratic Congress. Consequently, GYEEDA lacked any semblance of credible coordination since there is a clear absence of coherence of the way the program was handled in the various institutions and ministries because there was no law backing the establishment of GYEEDA. For example, a report from the field established that NYEP/ GYEEDA was managed by the Youth Ministry with representation from a variety of other agencies such as Ghana Education Service, Ghana Health Service, National Youth Authority, and the other private sector organizations, without the involvement of the beneficiaries of the program. These agencies and organizations managed the GYEEDA differently without coordinating with other agencies and organizations in charge of the administration of the same program. The developments resulted in huge duplication, with some service providers overlapping training services in the same localities. Available evidence from the field revealed that some of the modules were exclusively remitted for youth development while several others had initiatives and products that were not ostensibly youth-oriented. This situation made it difficult for the youth to benefit from the program which was initiated for them. This finding confirms the argument of social interdependence theory that the success of youth participation in the public policy process lies in the collaboration between stakeholders as a team in developing and implementing youth policies (Brown \& Paulus, 2002).

Prevalence of Diversity and Social Exclusion: Data from the field identified prevalence of diversity and social exclusion as a key issue that impinged on youth participation in GYEEDA, because they were considered as deficient in terms of knowledge, skills, and experience to engage in the decision-making process such as designing, planning, and implementation of the program although they were the beneficiaries of GYEEDA. The argument is that in Ghana, many of the youths have little or no level of education and hence are not better equipped to access information from the internet. Thus, the policymakers rather engaged the political functionaries from the top echelons of the National Democratic Congress Party in the decisionmaking process in respect of the preparation, approval, and implementation of the modules under the GYEEDA initiative. Nonetheless, as indicated by UNESCO (2004) for national youth policy to function 
effectively to meet the needs, wants and culture of the youth, it is imperative to engage local and regional agencies in the development initiatives in the action plan. This practice was commonly experienced by the youth because the GYEEDA initiative did not have any law guiding its operation in Ghana. This finding corroborates Greetje's (2009) submission that in African societies, patriarchy considers adults as people who manage and lead decision-making in the family and society. In this way, adults continue to maintain power and have control of resources, making youths dependent and subordinate to adults. This situation tends to contribute to the inferiority complex that hinders youth from participating in the decision-making process in society.

\section{Conclusion and Policy Implications}

This paper sought to unlock the challenging pathways of youth participation in GYEEDA in the Fourth Republic of Ghana. The study established that the meaningful spaces which are provided for the youth to participate in GYEEDA were very limited, due to a web of challenges such as insufficient access to information, over-politicization of youth policy, poor level of coordination of stakeholders of youth programs, and prevalence of diversity and social exclusion even though Ghana was signatories to numerous United Nations and Africa Youth Protocols and Charters, which required Africa governments to hasten the execution of youth participation in public policies process. A classic example is the Youth Decade Plan of Action (20092018) and African Youth Charter signed during the 17th Ordinary Summit held from 23rd June to 1st July 2011 in Malabo, Equatorial Guinea. Consistent with the foregoing discussion, it is argued that the provision of efficient and holistic guidelines for youth participation in public policies is a crucial step in Ghana. This is imperative because youth are the most marginalized during policymaking because policymakers repeatedly believe that they are inexperienced and immature to be engaged in such a process. Such impressions are erroneous and archaic, especially, due to the import of life transitions that take place exactly in youth.

Thus, if the policymakers anticipate a healthy, coherent and connected society for individuals to live happily and productively, youth are required to be provided with proper space in the public policy process. To accomplish this august goal, the National Youth Authority in collaboration with all the agencies and institutions in the sub-sector must strive to develop a long-term and coherent policy, which is consistent with the needs of youth in the society. Second, it is also crucial for policymakers to discontinue the overpoliticization of the policy process, and rather support youth to build their individual capacities. Important strategies in this respect include support for youth-led initiatives but also creating opportunities for intergenerational partnerships based on equality and trust. Third, there is an urgent need to put in place mechanisms to help promote efficient coordination of the institutions mandated to handle youth programs. This, in turn, will facilitate proper coordination by the institutions leading to the effective administration of youth initiatives for policy development. Finally, the issue of diversity and social exclusion must also be resolved by the policymakers to ensure that youth are brought on board to contribute their quota towards efficient designing, planning, and implementation of youth programs.

\section{References}

African Union. (2011). African youth decade 2009-2018 Plan of Action: Accelerating youth empowerment for sustainable development. Addis Ababa, Ethiopia.

Bessant, J. (2018). Young precariat and new work order? A case for historical sociology. Journal of Youth Studies, 1-19.

Brown, V. \& Paulus, P. (2002). Current perspectives and directions in making group brainstorming more effective recommendations from associative memory. Psychological Science, 11(6), 208-212.

Busse, B., Hashem-Wangler, A. \& Tholen, J. (2015). Two worlds of participation: Young people and politics in Germany. The Sociological Review, 63(2), 118-140.

Chamisa, S. F. \& Shava, E. (2016). Youth Involvement in Policy Making: A Case Study of South Africa. Journal of Social Sciences, 49(2), 165-174.

Checkoway, B. (1998). Involving young people in neighborhood development. Children and Youth Services Review, 20, 765-795.

Côté, J. E. (2014). Towards a new political economy of youth. Journal of Youth Studies, 17(4), 527-543. 
Dalton, R. J. (2017). The participation gap: Social Status and political inequality. Oxford University Press.

Deutsch, M. (1962). Cooperation and trust: Some theoretical notes. In J. R. Jones, Nebraska symposium on motivation. Lincoln, NE: University of Nebraska Press.

Dowding, K. (1996). Power. Buckingham: Open University Press.

Economic Commission for Africa. (2011). African youth report: Addressing youth education and employment nexus in the new global economy. Addis Ababa: Ethiopia. United Nations Economic Commission for Africa.

Falls, I., Bahhouth, V., Chuang, C. M. \& Bahhouth, J. (2014). Factors influencing students' perceptions of online teamwork. SAGE Open.

Gaiser, W., ve, J. D. \& Spannring, R. (2010). Youth and political participation, empirical results for Germany within a European context. Nordic Journal of Youth Research, 18(4), 427-450.

Ghana Statistical Service. (2014). Ghana living standard survey round 6 (GLSS6). Accra, Ghana: Labour Force Report.

Ghana Statistical Service. (2012). 2010 Population \& housing census national analytical report. Accra, Ghana.

Gough, K. V., Langevang, T. \& Owusu, G. (2013). Youth employment in a globalizing world.). International Development Planning Review, 35(2), 91-102.

Grauenkaer, L. \& Tufte, T. (2018). Development in practice youth-led communication for social change: Empowerment, citizen media, and cultures of governance in Northern Ghana Development in Practice, 28(3), 400-413.

Greetje, T. (2009). Youth policy and participation. Children and Youth Services Review, 31(5), 572-596.

Gutmann, A. \& Thompson, D. (2004). Why Deliberative Democracy. New Jersey: Princeton University Press.

Gyampo, R. E. (2015). Youth in parliament and youth representation in Ghana. Journal of Asian and African Studies, 50(1), $69-82$.

Gyampo, R. E. \& Debrah, E. (2012). The youth and party manifesto. The case of the 2012 General Elections, Journal of African Elections, 12(2), 96-114.

Gyampo, R. \& Debrah, E. (2012). The youth and party manifesto. The case of the 2012 General Elections. Journal of African Elections, 12(2), 96-114.

Gyampo, R. \& Obeng-Odoom, F. (2013). Youth participation in local and national development in Ghana. Journal of Pan African Studies, 5(9), 129-150.

Hart, J. \& Henn, M. (2017). Neoliberalism and the unfolding patterns of young people's political engagement and political participation in contemporary Britain. Societies, 7(4), 33.

Johnson, D. W. \& Johnson, R. T. (2010). New developments in social interdependence theory new developments in social interdependence theory. Genetic, Social, and General Psychology Monographs, 131(4), 285-358.

Langevang, T. (2008). Claiming place: The production of young men's street meeting places in Accra, Ghana. Geografiska Annaler: Series B, Human Geography, 90(3), 227-242.

Malley, K. (2005). Children and young people participating in PRSP processes - Lessons from Save the Children's Experience. London: Save the Children.

Ministry of Youth and Sports. (2013). National youth policy of Ghana: Towards an empowered youth, impacting positively on national development. Accra-Ghana: Accra Printing.

Molloy, D., White, C. \& Hosfield, N. (2002). Understanding youth participation in local government a qualitative study final report. National Centre for Social Research, 78(21), 71-98.

Mycock, A. \& Tonge, J. (2012). The party politics of youth citizenship and democratic engagement. Parliamentary Affairs, 65(1), 138-161.

NDPC. (2010). Report on the status of the youth benefits from the youth employment programs in Ghana. Accra-Ghana.

O’Toole, T. (2015). Beyond crisis narratives: Changing modes and repertoires of political participation among young people. In K. Kallio, S. Mills, \& T. Skelton, Politics, citizenship and rights. Singapore: Springer.

Patton, M. Q. (2002). Qualitative research and evaluation methods (3rd ed.) CA: Thousand Oaks Sage.

Percy-Smith, B. \& Thomas, N. (2009). A handbook of children and young people's participation. Oxford: Routledge.

Sloam, J. (2016). Diversity and voice: The political participation of young people in the European Union. The British Journal of Politics and International Relations, 18(3), 521-537.

Tarricone, P. \& Luca, J. (2010). Employees, teamwork, and social interdependence- a formula for a successful business? Team Performance Management. An International Journal, 8(3/4), 54-59. 
Tsekoura, M. (2016). Debates on Youth Participation: From Citizens Preparation to Active Social Agents. Rev. Katalysis, 19(1), Florianopolis.

UNESCO. (2004). Empowering Youth through National Policies. Paris.

United Nations. (2007). World youth report: Young people's transition to adulthood: Progress and challenges. Department of Economic and Social Affairs [DESA] New York, USA.

United Nations. (2003). World youth report: the global situation of young people. Department of Economic and Social Affairs [DESA]: New York, USA. 